\title{
Agnieszka Węglowska
}

Zespół Szkół Chemicznych w Krakowie

Uniwersytet Rolniczy w Krakowie

\section{Przedsiębiorczość wlasna młodzieży na przykładzie maturzystów krakowskich szkól średnich}

Młodzież bez wątpienia stanowi szczególną kategorię ludności. Potencjał, którym dysponuje, jest siłą napędową procesów zachodzących w społeczeństwie. Młodym ludziom nie sposób odmówić niezwykłej zdolności adaptacji do zachodzących zmian. Ta cecha pozwala im podejmować wyzwania i reagować na przemiany zachodzące w kraju bardziej elastycznie aniżeli osobom jakiejkolwiek innej kategorii wiekowej (Domalewski 2007). Młodzi ludzie stają przed szczególnym wyzwaniem: będąc u progu dorosłości, podejmują decyzje, które zaważą w dużej mierze na ich przyszłości. Nie są przy tym do końca świadomi, jak ważne są te decyzje i jakie będą ich skutki. Z jednej strony towarzyszy im niepewność dnia jutrzejszego, dorosłego życia, z drugiej strony - nie pozostają bierni i biorą los w swoje ręce, nie poddając się fali lekkodusznego stwierdzenia ,jakoś to będzie".

Młodzi ludzie to bardzo dynamiczna kategoria ludności, a to, jaką mamy młodzież dziś, wpłynie na kształt naszego kraju za kilka lat. Czy będą to ludzie wykształceni, z doświadczeniem zawodowym, przedsiębiorczy? Czy będą chętni do podejmowania nowych wyzwań? Od działań podejmowanych ,tu i teraz” zależy ich własna biografia, ale też sytuacja wszystkich Polaków. Wystarczy choćby wspomnieć o znaczeniu edukacji. Należy ona do tych dóbr, które są jednocześnie indywidualne i publiczne, które działają w skali mikro- i makroekonomicznej, a nawet globalnej. Edukacja ma znaczenie czysto utylitarne, dostarcza również wartości socjalnych i humanistycznych. Teorie i badania poświęcone związkom między edukacją a rozwojem ekonomicznym rozwinęły się szczególnie intensywnie w ostatnich latach, kiedy to dokonały się zmiany zarówno w gospodarce, jak i w sposobach kształcenia. Edukacja daje ludziom szanse na wzrost kwalifikacji niezbędnych w gospodarce, powoduje modernizację tejże gospodarki, ale także pozwala na lepsze rozumienie świata, nabycie umiejętności lepszej adaptacji do szybko zmieniających się warunków oraz umiejętności samodzielnego rozwiązywania swoich problemów (Golimowska 1999). Jednym ze składowych edukacji jest nauka przedsiębiorczości.

Definicji przedsiębiorczości jest bardzo wiele. Przedsiębiorczość jest uważana za jeden z czynników produkcji, obok ziemi, pracy i kapitału. Dla jednych przedsiębiorczość jest to wykorzystywanie szans i unikanie zagrożeń, a dla innych - umiejętność dostrzegania pomysłów oraz realizacji celów, zdolność do podejmowania ryzyka w celu zaspokojenia swoich i cudzych potrzeb (Michałków 2003). Przedsiębiorczość uważana jest za cechę wyuczoną, a nie wrodzoną. W większości krajów ma dobre konotacje, kojarzona jest z ciężką pracą, determinacją w dążeniu do sukcesu oraz wyrzeczeniami. Przedsiębiorczość kojarzy się także - zwłaszcza 
uczniom szkół średnich - z przedmiotem lekcyjnym. Z przedsiębiorczością mamy do czynienia wówczas, gdy skutki naszego działania zależą od tego, co i jak sami robimy. Ludzie przedsiębiorczy są z reguły bardzo pracowici, pełni optymizmu, chętni do stałego doskonalenia. Okazują oni szacunek dla pracy, gdyż wiedzą, czym jest praca i odpowiedzialność za swoje czyny (Michałków 2003). Właśnie na taki rodzaj przedsiębiorczości młodych chciano skierować uwagę. Wyrazem przedsiębiorczości w tak młodym wieku stały się wszystkie działania podejmowane przez uczniów w czasie wolnym od nauki, a mające na celu ich osobisty rozwój, doskonalenie umiejętności przydatnych w dalszej edukacji i pracy, wolontariat, pracę zarobkową czy pracę na rzecz środowiska lokalnego.

Zarówno teoria, jak i praktyka wskazują, że kształtowanie postaw przedsiębiorczych u młodzieży jest nieodzowne. Obecna sytuacja społeczno-gospodarcza, w której znalazł się nasz kraj, wymaga szczególnie od młodzieży przyjęcia nowej postawy, dzięki której będzie ona mogła znaleźć dla siebie odpowiednie miejsce w nowej rzeczywistości (Adamski, Trela 1999). Młodzież kończąca szkołę, szukająca swojego miejsca w dorosłym świecie, jest w tych poszukiwaniach często bezradna i zagubiona. Badania przeprowadzone w firmach zlokalizowanych na terenie Bielska-Białej wykazały, że najczęstszymi przyczynami rozwiązania umowy bądź w ogóle niezatrudniania młodzieży są: słaba znajomość obsługi komputera, brak lub słaba znajomość języków obcych, niskie kwalifikacje zawodowe, brak predyspozycji do wykonania określonych czynności, brak prawa jazdy, znikoma zdolność autoprezentacji, brak dodatkowych kwalifikacji zawodowych czy wreszcie brak wiedzy na temat sporządzania dokumentów aplikacyjnych. Wyniki badań informują, że młodzież posiada zbyt małą wiedzę na temat lokalnego rynku pracy oraz słabą znajomość metod poszukiwania wolnych miejsc pracy. Dynamiczny rozwój społeczny i gospodarczy Polski wymaga przygotowania młodzieży do uczestnictwa i tworzenia nowych form życia.

Lata szkolne są okresem formowania się struktury psychicznej i zrębów osobowości człowieka. W rozwoju osobowości ucznia należy zwrócić uwagę na jego własną aktywność, kreatywność, umiejętność krytycznego myślenia. Własna aktywność ułatwia rozwiązywanie problemów, daje poczucie większej wartości w kontaktach z otoczeniem i wskazuje drogę do sukcesu. Szkoła powinna przygotowywać do poradzenia sobie w sytuacjach, które staną się udziałem ucznia w dorosłym życiu. Absolwent powinien posiadać elementarne wiadomości i umiejętności autoprezentacji, sposobu prowadzenia rozmów z pracodawcą, wiedzieć, jakie dokumenty wymagane są przy zatrudnieniu i jak należy je sporządzać (Adamski, Trela 1999).

Przy podejmowaniu jakiegokolwiek działania konieczne jest poczucie własnej wartości, zaś niewiara we własne umiejętności i możliwości jest tym, co paraliżuje. Tym, co hamuje aktywność równie często, jest niezdolność do samodzielnego decydowania i brania odpowiedzialności za swe decyzje. Ważne jest, aby nauczyciele rozwijali w uczniach nie tylko wiedzę, ale i umiejętności, by kształtowali odpowiednio do nowej sytuacji społeczno-gospodarczej nowy typ młodego człowieka - człowieka kreatywnego, samodzielnego, komunikatywnego, odpowiedzialnego, myślącego - jednym słowem - przedsiębiorczego (Adamski, Trela 1999).

\section{Cele i metody badań}

Badania, których wyniki prezentuję w niniejszym opracowaniu, zostały przeprowadzone w kwietniu 2011 roku. Miały one charakter ilościowy, zostały przeprowadzone techniką wywiadu audytoryjnego. Narzędzie badawcze stanowił kwestionariusz ankiety. Dobór próby do badań był celowy i dogodnościowy. Badaniu zostały poddane klasy maturalne w dwóch krakowskich szkołach średnich: XXVI Liceum Ogólnokształcącym i Technikum Chemicznym z Zespołu Szkół Chemicznych oraz technikum z Zespołu Szkół Mechanicznych nr 2. Badania 
ostatecznie objęły 119 osób. Wśród nich zdecydowaną większość stanowiły dziewczęta: było ich $83(70 \%)$ w stosunku do 36 chłopców (30\%). Do technikum uczęszczało 76\% respondentów, a do liceum ogólnokształcącego - 24\%. Najwięcej uczniów pochodziło ze wsi (48,7\%). Niewiele mniejszą grupę stanowili uczniowie z dużych miast - 43,7\%. Uczniowie mieszkający w małych miastach stanowili $6,7 \%$ respondentów.

Jednym z celów badania była próba odpowiedzi na pytanie, czy młodzież wykazuje się postawą przedsiębiorczą - to znaczy, czy podejmuje wyzwania pozaszkolne, które wpłyną na kształt dalszej edukacji i pracy zawodowej. Przedsiębiorczość własną należy rozumieć tutaj jako inicjatywność, podejmowanie aktywności, dodatkowy wysiłek, którego celem jest realizacja zamierzonych przedsięwzięć.

\section{Wyniki badań}

Jednym z przejawów postawy przedsiębiorczej jest podejmowanie pracy. Badani maturzyści pytani o to, czy w ciągu ostatniego roku szkolnego podjęli pracę zarobkową, odpowiadali w większości twierdząco (61\%) (ryc. 1). Spośród 119 badanych 47 osób nie podjęło pracy, co stanowiło $39 \%$ ankietowanych.

Ryc. 1. Respondenci wg podjętego zatrudnienia w ciągu roku szkolnego $(N=119)$

\section{Czy w ciągu ostatniego roku szkolnego podjąłeś/podjęłaś pracę zarobkową?}

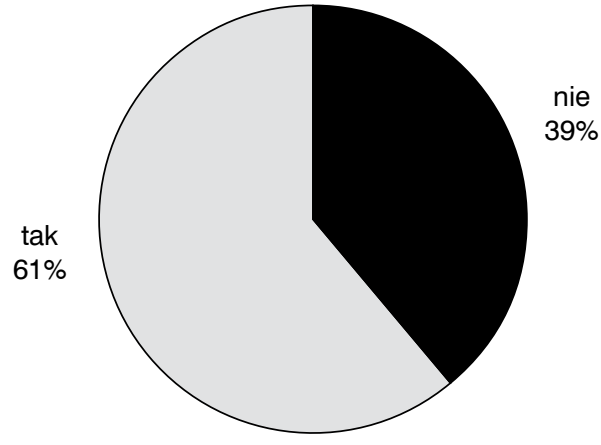

Źródło: opracowanie własne.

Uczniowie pracowali głównie w czasie wolnym od nauki - w okresie wakacji i ferii (27\%), a także w weekendy (19\%). Byli również tacy, którzy po skończonych zajęciach w szkole szli do pracy (5\%). Okazyjnie, kiedy nadarzyła się sposobność, pracę podjęło 10\% respondentów. Wartym odnotowania jest fakt, iż tylko jeden respondent potwierdził, że pracował w czasie, kiedy powinien przebywać w szkole.

Kim są ci młodzi ludzie, którzy w czasie wytężonej nauki i zbliżającej się matury zarabiają na swoje utrzymanie czy drobne przyjemności? Spośród uczniów podejmujących pracę częściej byli to chłopcy niż dziewczęta; pracowało prawie $70 \%$ uczniów oraz prawie $60 \%$ uczennic (tab. 1). W takim samym stopniu pracę podejmowali uczniowie liceum, czyli de facto osoby nieposiadające żadnego przygotowania zawodowego, jak i uczniowie techników, którzy z racji typu szkoły zetknęli się z zajęciami przygotowującymi do zawodu, jak i odbywali praktyki poza szkołą. Pracujących uczniów nie różnicował też status finansowy rodziny: podejmowali 
oni pracę bez względu na to, jak przedstawiała się sytuacja materialna w ich rodzinach. I tak pracowali zarówno uczniowie z domów, gdzie miesięczne dochody pozwalają żyć komfortowo, jak i tacy, których rodzina ma duże trudności z finansowaniem najważniejszych potrzeb.

Tab. 1. Wpływ płci, typu szkoły i sytuacji finansowej rodziny na podjęcie pracy przez respondentów $(\mathrm{N}=119)$

\begin{tabular}{|l|c|c|c|}
\hline \multirow{2}{*}{ Zmienne niezależne } & \multicolumn{2}{c|}{$\begin{array}{c}\text { Czy w ciągu ostatniego roku szkolnego } \\
\text { podjąleś/podjęlaś pracę? }\end{array}$} \\
\cline { 2 - 4 } & $\begin{array}{c}\text { tak } \\
{[\%]}\end{array}$ & $\begin{array}{c}\text { nie } \\
{[\%]}\end{array}$ \\
\hline \multirow{3}{*}{ Płeć } & kobieta & 58 & 42 \\
\hline \multirow{3}{*}{ Typ szkoły } & mężczyzna & 67 & 33 \\
\hline \multirow{4}{*}{$\begin{array}{l}\text { Sytuacja finansowa } \\
\text { rodziny }\end{array}$} & LO & 62 & 38 \\
\cline { 2 - 4 } & technikum & 60 & 40 \\
\cline { 2 - 4 } & bardzo dobra & 60 & 40 \\
\cline { 2 - 4 } & dobra & 61 & 39 \\
\cline { 2 - 4 } & przeciętna & 63 & 37 \\
\cline { 2 - 4 } & poniżej przeciętnej & 60 & 40 \\
\hline
\end{tabular}

Źródło: opracowanie własne.

Zatem co, jeśli nie płeć ani sytuacja materialna rodziny, w znacznym stopniu wpłynęło na podjęcie przez uczniów pracy? Aby odpowiedzieć na to pytanie, maturzystów zapytano o motywy podejmowania zatrudnienia. Okazało się, iż główną przesłanką, która skłaniała badanych maturzystów do podjęcia pracy, była w znakomitej większości $(30,3 \%)$ chęć zdobycia dodatkowych pieniędzy, czyli jak to zostało ujęte w ankiecie „dorobienie do kieszonkowego”. Drugim w kolejności powodem była chęć uniezależnienia się od rodziców $(8,4 \%)$. W dalszej kolejności badani wskazywali na trudną sytuację rodzinną $(7,6 \%)$ i w związku z tym konieczność pomocy finansowej rodzicom. Ważnym czynnikiem podejmowania pracy była także chęć zdobycia doświadczenia $(6,7 \%)$ oraz uzyskania jakichkolwiek pieniędzy ze względu na to, że uczniowie nie dostawali pieniędzy od nikogo $(6,7 \%)$.

Najbardziej popularnym sposobem poszukiwania pracy było korzystanie z pomocy znajomych $(40 \%)$ oraz rodziców (9\%). Wydawać by się mogło, że najbardziej oczywisty sposób poszukiwania pracy, czyli przez odpowiadanie na zamieszczone ogłoszenia, będzie częstym sposobem, a jednak skorzystało z niego niespełna 7\% spośród pracujących maturzystów. Nieco ponad 3\% badanych samodzielnie roznosiło dokumenty aplikacyjne, a zaledwie jedna osoba skorzystała z agencji pracy tymczasowej podczas poszukiwania miejsca zatrudnienia.

W ankiecie padło też pytanie o to, czy maturzyści w ciągu ostatniego roku pracowali społecznie. Odpowiedzi twierdzącej udzieliło 23\% badanych. Pozostałe 77\% uczniów nie pracowało społecznie. Warto więc zauważyć, że młodzież chętniej podejmuje prace płatne, takie, które wpłyną na zasobność jej portfela. Spośród osób, które wykazały się aktywnością społeczną, największa liczba (dziewięć osób) pracowała na rzecz fundacji, organizacji młodzieżowych, a także - w pojedynczych przypadkach - wykonywała prace na rzecz samorządu szkolnego i parafii. 
Okazało się, że spośród 72 osób, które podjęły pracę zarobkową, charytatywnie pracowało 17 osób (23,6\%). Natomiast w grupie osób niepracujących zarobkowo 10 osób (21,3\%) pracowało w charakterze wolontariuszy. Dane o tym, czy badana młodzież łączyła pracę zarobkową z pracą społeczną, czy też nastawiła się jedynie na jeden z rodzajów pracy: zarobkową lub charytatywną, przedstawia tabela 2 .

Tab. 2. Praca zarobkowa a praca społeczna badanych respondentów $(\mathrm{N}=119)$

\begin{tabular}{|c|c|c|c|c|c|c|}
\hline & & \multicolumn{4}{|c|}{$\begin{array}{c}\text { Czy w ciągu ostatniego roku } \\
\text { zdarzyło Ci się pracować społecznie? }\end{array}$} & \multirow{3}{*}{ razem } \\
\hline & & \multicolumn{2}{|c|}{ tak } & \multicolumn{2}{|c|}{ nie } & \\
\hline & & częstość & $\%$ & częstość & $\%$ & \\
\hline \multirow{3}{*}{$\begin{array}{l}\text { Czy w ciągu ostatniego roku } \\
\text { szkolnego podjąłeś/podjęlaś } \\
\text { pracę? }\end{array}$} & tak & 17 & 23,6 & 55 & 76,4 & 72 \\
\hline & nie & 10 & 21,3 & 37 & 78,7 & 47 \\
\hline & razem & 27 & 22,7 & 92 & $77,3 \%$ & 119 \\
\hline
\end{tabular}

Źródło: opracowanie własne.

Ważnym aspektem badań była identyfikacja, w jaki sposób młodzi ludzie wykorzystują swój wolny czas. W pytaniu wyróżniono cztery rodzaje aktywności. Były to: praca zarobkowa, nauka, zainteresowania i hobby oraz życie towarzyskie. Zadaniem respondenta było określenie, czy powyższe zajęcia wykonuje regularnie, od czasu do czasu, czy może w ogóle. Jak wykazały badania, młodzież poświęca regularnie czas na życie towarzyskie ( $64 \%$ badanych) oraz naukę.

Ryc. 2. Sposoby spędzania wolnego czasu przez maturzystów ( $N=119)$

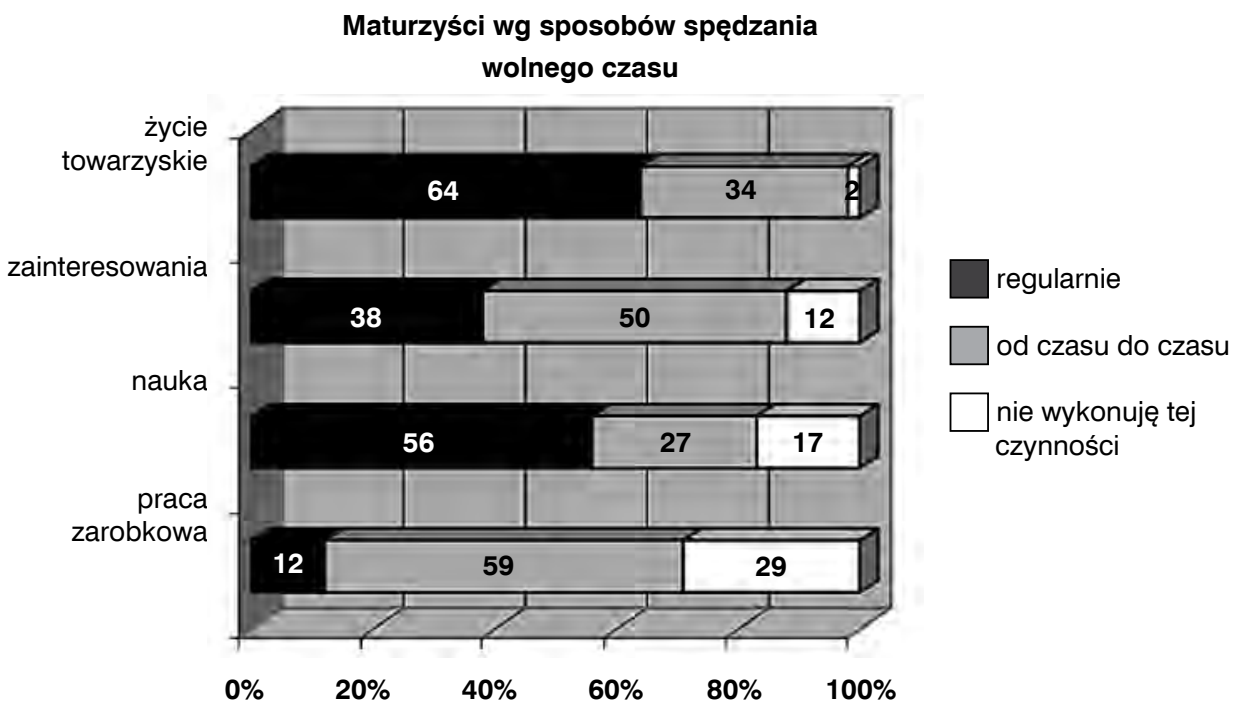

Źródło: opracowanie własne. 
Kolejne pytania dotyczyły spraw finansowych. W kwestionariuszu znalazły się dwie kwestie: oszczędzania oraz kieszonkowego. Kwestie te były przedmiotem badania, ponieważ posiadanie oszczędności przez uczniów uważa się za przejaw swego rodzaju zapobiegliwości i systematyczności i dążenie do realizacji pragnień. Jak się bowiem okazało, młodzież zazwyczaj oszczędza w konkretnym celu.

Wyniki badań wskazują, że prawie 70\% badanych posiadało własne oszczędności, przy czym jako główne powody oszczędzania maturzyści podawali chęć kupienia sobie czegoś (41\%) oraz fakt, że lubią mieć odłożone pieniądze (40\%). Nieco ponad $16 \%$ ze wszystkich osób posiadających oszczędności wyniosło zwyczaj gromadzenia pieniędzy z domu. Trzy osoby odpowiedziały, że oszczędzają na wyjazdy wakacyjne. Ciekawy jest fakt, iż w przeważającej części oszczędności posiadają zarówno chłopcy, jak i dziewczęta. Zestawiając dane o posiadanych oszczędnościach z sytuacją finansową rodziny, można stwierdzić, że nie widać dużych różnic pomiędzy uczniami z tzw. bogatych domów a uczniami z przeciętnych rodzin. Znacznie jednak w tym względzie odbiegają od nich uczniowie pochodzący z rodzin, które mają trudności z finansowaniem swoich potrzeb - nie mają oni żadnych oszczędności (tab. 3).

Tab. 3. Finanse badanych maturzystów $(\mathrm{N}=119)$

\begin{tabular}{|c|c|c|c|c|c|c|}
\hline \multirow{2}{*}{$\begin{array}{c}\text { Czy posiadasz } \\
\text { oszczędności? }\end{array}$} & \multicolumn{2}{|c|}{ Płeć } & \multicolumn{3}{c|}{ Sytuacja finansowa rodziny } \\
\cline { 2 - 7 } & kobieta & mężczyzna & $\begin{array}{c}\text { bardzo } \\
\text { dobra }\end{array}$ & dobra & przeciętna & $\begin{array}{c}\text { poniżej } \\
\text { przeciętnej }\end{array}$ \\
\hline Tak & $70 \%$ & $72 \%$ & $76 \%$ & $69 \%$ & $75 \%$ & $20 \%$ \\
\hline Nie & $30 \%$ & $28 \%$ & $24 \%$ & $31 \%$ & $25 \%$ & $80 \%$ \\
\hline
\end{tabular}

Źródło: opracowanie własne.

Tym, którzy nie zarabiali ani nie odkładali pieniędzy, pozostawało kieszonkowe, czyli pieniądze, które regularnie bądź od czasu do czasu dostawali od rodziców. Takie osoby stanowiły większość badanych (73\%). Osoby, które otrzymywały pieniądze do własnej dyspozycji, przeznaczały je głównie na jedzenie, ubrania, rozrywki kulturalne oraz imprezy i wyjścia na miasto ze znajomymi. Pojedyncze odpowiedzi respondentów wskazywały, że wydawali oni kieszonkowe na alkohol, kosmetyki czy bilety MPK.

Sumy pieniędzy, które maturzyści dostawali do dyspozycji, są różne. Najwięcej, bo 1/3 badanych, otrzymywała kieszonkowe w wysokości ponad 200 zł na miesiąc, prawie co czwarty otrzymywał do $50 \mathrm{zł}$ na miesiąc. Między 150-200 zł dostawało 10\% badanych, 15\% otrzymywało 51-100 zł, z kolei 100-150 zł dostawało 18\% badanych.

Kolejnym problemem, którego dotyczyła ankieta, było dokształcanie się młodych ludzi. Przez dokształcanie należy tutaj rozumieć uczestnictwo w kursach przygotowawczych na studia, kursach językowych, udział w różnego rodzaju projektach realizowanych w szkołach czy pobieranie korepetycji. Należy więc odróżnić dokształcanie od normalnych obowiązków uczniowskich, czyli codziennego przygotowywania się do lekcji, odrabiania prac domowych czy czytania lektur. Dokształcanie jest związane z poszerzaniem kompetencji, które mogą być przydatne w pracy bądź w dostaniu się na wybrany kierunek studiów.

Dokształcanie jest ważne, zwłaszcza dziś, kiedy duży nacisk kładzie się na naukę przez całe życie i konieczność bycia elastycznym na rynku pracy, czyli posiadanie umiejętności, które można wykorzystać w różnych zawodach. Podejmowanie dodatkowego wysiłku, jakim jest nauka ponad to, co jest wymagane w szkole, świadczy o tym, iż młodzi chcą mieć realny wpływ 
na swoje życie, poprzez wiedzę, która uczyni ich konkurencyjnymi w przyszłości - na studiach czy w pracy. Przeprowadzone badania wskazują, iż dokształcało się nieco ponad 52\% maturzystów.

Badania miały również na celu określenie stosunku maturzystów do życia i pracy. Aby określić tę postawę, przedstawiono im pięć hipotetycznych sytuacji, z których mogliby skorzystać, gdyby dostali w spadku ogromną sumę pieniędzy. Okazało się, że największa liczba respondentów (47\%) wybrała opcję „,korzystam z uroków życia, ale dzielę majątek na części z jednej korzystam, a drugą wkładam na lokatę, bądź inwestuję w coś, co przyniesie mi zysk". Drugą w kolejności ze względu na popularność (25\%) była odpowiedź „Jestem bogaty - to miło, ale pracuję, bo życie bez pracy nie ma dla mnie sensu, a ja lubię realizować się poprzez działanie”. Prawie 17\% badanych zaznaczyło odpowiedź „Jestem bogaty - to miło, ale pracuję, bo ciągłe korzystanie z uroków życia też się kiedyś znudzi”. Młodzi ludzie wybierali rozsądnie - jeśli mieli pieniądze, chętnie je inwestowali choć w części, ale nawet w momencie, kiedy stali się na chwilę bogaczami, dostrzegali wartość pracy, poprzez którą mogą się realizować i dzięki której nie będą się nudzić.

Podsumowaniem badań było pytanie o to, w jaki sposób maturzyści oceniają samych siebie. Czy uważają siebie za osoby przedsiębiorcze? Okazuje się, iż odpowiedź na to pytanie przysporzyła uczniom trudności. Zdecydowanie ,tak” odpowiedziała połowa badanych, a aż 43\% respondentów nie potrafiło określić, czy jest osobą przedsiębiorczą, $8 \%$ nie uznało się za osoby przedsiębiorcze (ryc. 3).

Ryc. 3. Ocena swojej osoby $(\mathrm{N}=119)$

\section{Czy uważasz się za osobę przedsiębiorczą?}

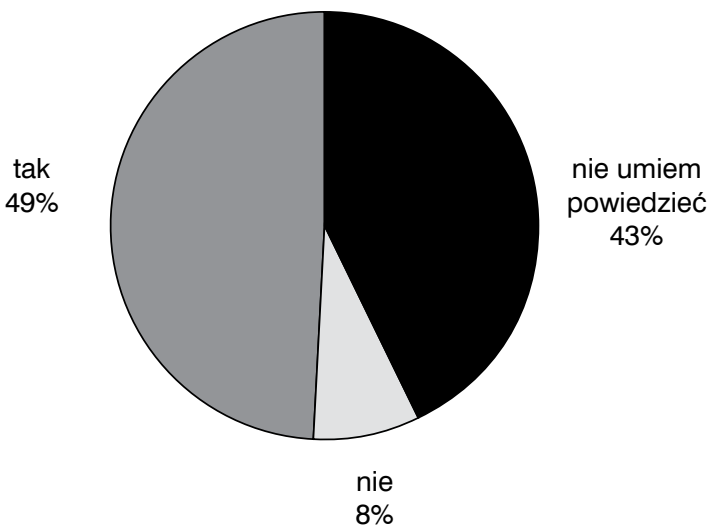

Źródło: opracowanie własne.

Ciekawych wniosków dostarcza analiza tego, czy maturzyści uważają się za przedsiębiorczych w podziale na płeć, miejsce zamieszkania i typ szkoły, do której uczęszczają. Nie ma dużych różnic pomiędzy dziewczętami a chłopcami - połowa z nich określiła siebie mianem przedsiębiorczych, choć więcej uczennic pozostawało w tym względzie niezdecydowanych (tab. 4). Interesujące jest zdanie uczniów pochodzących ze wsi - połowa z nich uważa się za przedsiębiorczych, a 5\% uważa, że nie są przedsiębiorczy. 
Tab. 4. Poczucie bycia przedsiębiorczym a płeć, miejsce zamieszkania i typ szkoły ( $N=119)$

\begin{tabular}{|c|c|c|c|c|c|c|c|}
\hline \multirow{2}{*}{$\begin{array}{c}\text { Czy uważasz } \\
\text { siebie za osobę } \\
\text { przedsię- } \\
\text { biorczą? }\end{array}$} & \multicolumn{2}{|c|}{ Pleć } & \multicolumn{2}{c|}{ Miejsce zamieszkania } & \multicolumn{2}{c|}{ Typ szkoły } \\
\cline { 2 - 8 } & kobieta & mężczyzna & wieś & $\begin{array}{c}\text { male } \\
\text { miasto } \\
{[\%]}\end{array}$ & $\begin{array}{c}\text { duże } \\
\text { miasto } \\
{[\%]}\end{array}$ & $\begin{array}{c}\text { liceum } \\
{[\%]}\end{array}$ & $\begin{array}{c}\text { techni- } \\
\text { kum } \\
{[\%]}\end{array}$ \\
\hline Tak & 48 & 50 & 50 & 50 & 46 & 52 & 48 \\
\hline Nie & 7 & 11 & 5 & 0 & 13 & 10 & 8 \\
\hline $\begin{array}{c}\text { Nie potrafię } \\
\text { powiedzieć }\end{array}$ & 45 & 39 & 45 & 50 & 41 & 38 & 44 \\
\hline
\end{tabular}

Źródło: opracowanie własne.

Młodzież z małych miast w połowie przypadków nie potrafiła się określić, ale daleka była od tego, by mówić, że zdecydowanie nie jest przedsiębiorcza.

Nazwanie siebie samego osobą przedsiębiorczą może być determinowane różnymi czynnikami. Ciekawe wydawało się zestawienie takich zmiennych, jak praca i dokształcanie z pytaniem, w którym respondenci musieli się zdeklarować, w jaki sposób oceniają samych siebie (tab. 5).

Tab. 5. Praca zarobkowa i dokształcanie się a poczucie bycia przedsiębiorczym $(\mathrm{N}=119)$

\begin{tabular}{|l|c|c|c|}
\cline { 2 - 4 } \multicolumn{1}{c|}{} & \multicolumn{3}{|c|}{ Czy uważasz się za osobę przedsiębiorczą? } \\
\cline { 2 - 4 } \multicolumn{1}{c|}{} & tak & nie & $\begin{array}{c}\text { nie umiem } \\
\text { powiedzieć }\end{array}$ \\
\hline $\begin{array}{l}\text { Uczniowie, którzy w ciągu ostatniego roku } \\
\text { szkolnego podjęli pracę zarobkową (N = 72) }\end{array}$ & $51 \%$ & $10 \%$ & $39 \%$ \\
\hline $\begin{array}{l}\text { Uczniowie, którzy w wolnym czasie się } \\
\text { dokształcają (N = 57) }\end{array}$ & $47 \%$ & $10 \%$ & $43 \%$ \\
\hline
\end{tabular}

Źródło: opracowanie własne.

Spośród uczniów, którzy w ciągu ostatniego roku szkolnego pracowali (72 osoby), 51\% określiło siebie mianem przedsiębiorczych. Z grupy pracujących maturzystów aż 28 osób nie potrafiło siebie określić, natomiast tych, którzy podjęli pracę, a nie uważali się za osoby przedsiębiorcze, było 10\%. Analogicznie sytuacja wyglądała w przypadku dokształcania - wielu spośród tych, którzy doskonalili swoje kompetencje, nie uważało się za osoby przedsiębiorcze. Okazuje się więc, że w tak młodym wieku można być aktywnym na polu zawodowym, uczestniczyć w nadprogramowych zajęciach i jednocześnie nie dostrzegać u siebie cechy takiej, jak przedsiębiorczość.

Jak już wspomniano, definicji przedsiębiorczości jest bardzo wiele. Jest to pojemne hasło i dla każdego z nas bycie przedsiębiorczym może oznaczać coś innego. Wśród wielu rodzajów przedsiębiorczości wyróżnia się przedsiębiorczość własną, która powinna być widziana jako wkład i wysiłek w rozwój osobisty i zawodowy. Sądząc po wynikach przeprowadzonych badań i odpowiedzi uczniów dotyczących ich pracy zarobkowej, sposobu wykorzystywania wolnego czasu oraz ich stosunku do pieniędzy, należy stwierdzić, że badani maturzyści są osobami przedsiębiorczymi, a jednocześnie zdają się nie dostrzegać u siebie postawy przedsiębiorczej. 
Młodzież nie łączy faktu samodzielnego zarabiania pieniędzy czy wykorzystywania swojego wolnego czasu w sposób twórczy i pożyteczny z byciem przedsiębiorczym. Stąd potrzeba uświadomienia jej, czym jest przedsiębiorczość, wyzwalania u niej tej cechy, sprawiania, aby przedsiębiorczość nie była jedynie nazwą przedmiotu szkolnego, ale też zespołem cech i postawą, którą młodzi w trakcie nauki szkolnej i dalszym życiu powinni wyzwalać i pielęgnować w sobie z korzyścią dla siebie i swojego otoczenia.

\section{Literatura}

1. Adamski A., Trela N., 1999, Kształtowanie postaw przedsiębiorczości u młodzieży [w:] Młodzież w sytuacji zmian gospodarczych, edukacyjnych, społecznych i kulturowych, W. Kojs, R. Mrózek, R. Studenski (red.), Cieszyn.

2. Domalewski J., 2007, Przyszłość wsi polskiej z perspektywy dążeń życiowych młodzieży [w:] Społeczno-ekonomiczne aspekty rozwoju polskiej wsi, M. Błąd, D. Klepacka-Kołodziejska (red.), IRWiR PAN, Warszawa.

3. Golimowska S., 1999, Edukacja i runek pracy, Raporty CASE, Warszawa.

4. Michałków I., 2003, Przedsiębiorczość młodzieży a szanse sukcesu na europejskim rynku pracy [w:] Przedsiębiorczość młodzieży, J. Merski, K. Piotrkowski (red.), Wyższa Szkoła Ekonomiczna, Warszawa.

\section{Youth's own entrepreneurship based on the example of A-level students of secondary schools in Kraków}

Time that teenagers spend in secondary schools may be perceived as time of ease and folly. Yet, on the other hand, it is time of making serious decisions. The decisions that are made at this stage of life affect the individual's future to a great extent. Furthermore, actions taken at that time may appear fruitful further down the road: at university or in a job. The youth is believed to live it up and spend time recklessly without any concern about the future. However, the research that I carried out in April 2011, presents a different picture of the youth.

A hundred and nineteen A-level students from two secondary schools in Kraków took part in the research. The study lasted one month and selection of sample was intentional and made within the accessibility of the research material. The research included three areas of interest: the first concerned entrepreneurial attitudes, the second - secondary school education and the third - the prospects in the sphere of education and professional career. The research indicated that $60 \%$ of A-level students took up a job during the last year of their secondary school education. $23 \%$ of the respondents were involved in social work. It was proved that A-level students devote their time both to socializing and studying. $48 \%$ of the respondents get engaged in different forms of extracurricular activities in their spare time. In spite of the initiative they show, only $49 \%$ of A-level students consider themselves entrepreneurial and $43 \%$ are not able to determine whether they are entrepreneurial or not. 